\title{
Werkdruk in Europa: omvang, ontwikkelingen en verklaringen
}

\author{
Irene Houtman, Peter Smulders \& Ruurt van den Berg*
}

Om (1) omvang en trends in werkdruk in Europa te beschrijven, (2) Nederland hierop in Europa te positioneren, en (3) oorzaken van werkdruk in Europa te identificeren is een gegevensbestand geanalyseerd met informatie over arbeid en gezondheid van een representatieve steekproef werkenden uit de Europese lidstaten anno 1990, 1995 en 2000. Per lidstaat ging het om 1000-1500 interviews per meetjaar.

Bijna 60 procent werkt in Europa minstens de helft van de werktijd in een hoog tempo of wordt met deadlines geconfronteerd (2000: $E U=59 \% ; N L=68 \%$ ). Dit was rond 1990 een veel geringer percentage van de werkenden. Verklaringen voor een hoge werkdruk zijn de hoge fysieke taakeisen, de grote taakcomplexiteit, en het werken met de computer. Voor mannen blijkt daarnaast het aantal gewerkte uren en telewerken een belangrijker bijdrage van hoge werkdruk dan voor vrouwen. Voor lage inkomens draagt fysieke werkbelasting, monotoon werk en afwijkende werktijden bij aan een hoge werkdruk.

Trefwoorden: werkdruk, tijdsdruk, taakautonomie, trends, Europa

\section{Inleiding}

Werkdruk is nog steeds actueel in Nederland. Het is, samen met werkstress en psychische klachten als burn-out en depressie, een maatschappelijk veel besproken en beschreven onderwerp. Hoewel de overheid uit is op minder regelgeving, laat ze voor psychosociale arbeidsbelasting, waaronder expliciet werkdruk wordt genoemd, ruimte om een 'nationale kop' in de Arboregelgeving te behouden. ${ }^{1}$ Op andere risico's moet Nederland volgens staatssecretaris Van Hoof maar niet boven het Europese maaiveld uitkomen. De werkdruk in Nederland, geoperationaliseerd als 'regelmatig in een hoog werktempo moeten werken', steeg over een periode van zo'n twintig jaar (sinds de eerste echte start van een arbeidsomstandighedenregistratie in 1977; CBS $)^{2}$ gestaag, maar blijkt sinds 1997 af te vlakken (Otten \& Houtman, 2002; Smulders \& Houtman, 2004). Een ander aspect van werkdruk, werken onder tijdsdruk, zoals sinds 1997 is opgenomen in de EBB (Enquête Beroepsbevolking, http://www.cbs.nl/nr/ rdonlyres/61c831cd-22c-4a03-811b-af84 $88 \mathrm{ef} 23 \mathrm{~d} 3 / 0 / \mathrm{pb0} 4 \mathrm{n} 102$.pdf) daalt zelfs enigszins sinds 1999. Er blijkt echter sprake van grote verschillen tussen sectoren in het percentage dat zegt regelmatig in een hoog tempo te moeten werken: daar waar werkenden in de financiële instellingen recentelijk een daling in de ervaren werkdruk laten zien, laten werkenden in het onderwijs, de gezondheidszorg en de horeca over dezelfde periode een stabilisering van werktempo zien op hoog niveau. De landbouw die gemiddeld lager scoort op werktempo dan deze laatstgenoemde sectoren laat daarentegen onlangs weer een stijging zien (Andries et al., 2004).

In deze bijdrage vragen we ons allereerst af hoe werkdruk zich op Europees niveau heeft ontwikkeld, en hoe Nederland zich op werkdruk positioneert tussen andere Europese lan-

\footnotetext{
* De auteurs zijn werkzaam bij TNO Kwaliteit van Leven I Arbeid; Correspondentieadres: Irene Houtman, Postbus 718, 2130 AS Hoofddorp, E-mail: i.houtman@arbeid.tno.nl. De auteurs danken hun collega Ernest de Vroome voor statistisch/grafische ondersteuning.
} 
den. Daarnaast willen we onderzoeken wat oorzaken zijn van werkdruk. We willen hierbij aansluiten op twee recente artikelen over oorzaken van werkdruk op basis van Nederlandse gegevens (Smulders \& Houtman, 2004; Wiezer et al., 2005), maar we willen de blik op dit onderwerp in deze bijdrage verbreden tot Europa. In het artikel van Smulders en Houtman (2004) werd al duidelijk dat er feitelijk weinig onderzoek is gedaan naar de oorzaken van werkdruk. Ook Kristensen en anderen (2004) onderschrijven het gebrek aan theoretisch en methodologisch onderzoek gericht op het begrip werkdruk. Dit ondanks het feit dat het één van de belangrijkste aspecten van onderzoek naar de psychosociale werkomgeving is, getuige het aantal theoretische benaderingen waarin werkdruk of kwantitatieve taakeisen een rol spelen, zoals in theorieën over de Person-Environment-fit, het Demand-Control Model, het onderzoek naar burn-out of het Effort-Reward-Imbalance Model. Smulders en Houtman (2004) laten zien dat er vooral uitgebreid onderzoek gedaan is naar de effecten van werkdruk, en er veel gerapporteerd is over diagnosemethoden, maatregelen, stappenplannen en oplossingsrichtingen voor werkdruk. In het artikel van Smulders en Houtman (2004) wordt geconcludeerd dat onderzoek naar de oorzaken van werkdruk een opvallende lacune blijkt, terwijl dit aspect juist belangrijke consequenties kan hebben voor de aanpak ervan. Kristensen en anderen (2004) laten tevens zien dat met name werkenden in de zogenaamde 'blauwe boorden'-beroepen gevoeliger zijn voor werkdrukvragen die de hoeveelheid werk betreffen, terwijl de 'witte boorden' vooral gevoelig lijken voor werkdrukvragen die over 'tijd' gaan. Als er een dergelijke differentiatie tussen werkenden in blauwe- en witteboordenfuncties is op het aspect van werkdruk, zou het goed kunnen zijn dat de oorzaken hiervan tussen beide groepen van werknemers ook verschillen.

Deze bijdrage borduurt (mede) voort op het artikel van Smulders en Houtman $(2004)$ en Wiezer, Smulders en Nelemans (2005), behalve dat er nu in een Europees bestand gekeken wordt om (ook) oorzaken van werkdruk in kaart te brengen. Het begrippenkader dat in die publicaties is gebruikt wordt ook hier gehanteerd. Smulders en Houtman (2004) concluderen dat de belangrijkste voorspellers van werkdruk de complexiteit en onvoorspelbaarheid van het werk zijn, zwaar en repeterend werk, emotioneel zwaar werk, beeldschermwerk en leidinggevend werk. Wiezer, Smulders en Nelemans (2005) formuleerden enkele hypothesen ten aanzien van (organisatorische) voorspellers van werkdruk en vonden in volgorde van belangrijkheid dat de inhoud van het werk (vooral zwaar werk en inwerktijd), procesvernieuwingen, complexiteit en instabiliteit van de omgeving, de mate van flexibilisering en regelmogelijkheden voorspellend waren voor werkdruk.

Een opvallende overeenkomst in beide onderzoeken bleek de voorspellende waarde van fysieke belasting. Dit werd geïnterpreteerd als dat dit vooral duidde op ontstane vermoeidheid waardoor vervolgens hoge taakeisen ook minder makkelijk konden worden gehanteerd. Het probleem hier zit vooral in de causaliteit. Ook in dit onderzoek kan dat niet echt worden verholpen, omdat ook hier steeds sprake is van onafhankelijke steekproeven, en er geen daadwerkelijk causaal verband kan worden aangetoond. Wel kan worden verondersteld dat in die functiegroepen waar relatief veel fysieke belasting aanwezig is, dit effect groter zal zijn.

Daarnaast is vooral in het onderzoek van Wiezer en anderen (2005) te zien dat diverse regelmogelijkheden voorspellend zijn voor werkdruk. Dit is iets dat strookt met het sociotechnische gedachtegoed, namelijk dat gebrekkige regelmogelijkheden leiden tot, dus voorafgaan aan regelproblemen zoals werkdruk (Vaas et al., 1995). Het DC-S-model vooronderstelt een gelijkwaardige risicorol van eisen en regelmogelijkheden, en stelt dat vooral de combinatie van onvoldoende regelmogelijkheden en taakeisen tot problemen leidt, maar dat de aanwezigheid van zowel eisen als regelmogelijkheden tot groei en ontwikkeling van werkenden zal leiden. Hoewel dit onderzoek vanwege de keuze voor het Europese 'bronbestand' niet zal leiden tot identificatie van oorzaken van psychische klachten, gaat het wel degelijk om de identificatie van factoren die nauw samenhangen met het ontwikkelen van werkdruk en psychische klachten. 
Er zijn enkele aspecten die niet goed konden worden onderzocht op hun voorspellende waarde voor werkdruk in de eerdergenoemde onderzoeken. Allereerst gaat het hierbij om de privésituatie. De interferentie tussen werk en de privésituatie is een opkomend aandachtspunt. Of het combineren van werk en zorgtaken tot meer psychische vermoeidheid of psychische klachten leidt, is niet ondubbelzinnig vastgesteld, maar dat het een risico vormt dat bijdraagt aan (uitval als gevolg van) psychische vermoeidheid, vooral bij vrouwen is aannemelijk (Breedveld \& Van den Broek, 2004). Molenaar-Cox en Van Deursen (2003, zie Breedveld \& Van den Broek, 2004) laten zien dat 21 procent van diegenen die langdurig verzuimen met psychische klachten dit doet vanwege werk, en waarbij 24 procent alleen privéredenen als oorzaak noemt, terwijl $44 \%$ in dat verband van een combinatie van werk en privé spreekt. Daarnaast vertonen in Nederland met name erg veel vrouwen in de leeftijd tussen de 25 en 35 jaar een verhoogde mate van arbeidsongeschiktheid (zie o.a. Veerman et al., 2001). Breedveld en Van den Broek (2004) wijzen erop dat het combineren van taken per definitie betekent dat men concessies doet en laveert tussen elk voor zich tamelijk veeleisende instituties /die van het carrièrepad en van het ouderschap), waarbij in de samenleving het 'combinatieethos' nog niet volledig is ingeburgerd. Deze dubbelrol wordt zowel in Nederland als in andere Europese lidstaten vooral vervuld door vrouwen (Kauppinen et al., 2003). Het combineren van werk en privé, of de belasting vanuit de thuissituatie lijkt dus een interessante, nieuwe dimensie, wellicht met name onder vrouwen, om naast de reeds eerder geïdentificeerde oorzaken van werkdruk ook als oorzaak van werkdruk mee te nemen. Verwacht wordt dat de invloeden vanuit de thuissituatie het werk (of andersom) op de psychische gemoedstoestand vooral zullen optreden bij werkende vrouwen, en minder bij werkende mannen. Mannen zijn vooral minder tot niet blootgesteld aan eisen vanuit de thuissituatie.

Ten slotte worden ook technologische ontwikkelingen zoals het werken met de computer gezien als een factor die werkdruk zou kunnen verhogen. Zo biedt het de mogelijkheid om te kunnen telewerken, waardoor thuiswerken, ook buiten de 'gewone' werktijden mogelijk is. Telewerken zou de 'afgrensbaarheid' van werk en privé kunnen verminderen, wat de kans om overspannen te raken vergroot (Bensing \& Schreurs, 1995; Zijlstra et al., 1996). Anderzijds zou telewerken ook kunnen worden gezien als een mogelijkheid om werk en privé makkelijker te kunnen combineren. Het draagt tenslotte bij aan de flexibiliteit waarmee men zijn werk zou kunnen uitvoeren. Als dat laatste het geval zou zijn, zou het telewerken met name bij vrouwen samenhangen met een lagere werkdruk. Verwacht wordt dat telewerken bij mannen vooral de grenzen tussen werk en privé aantast en hierdoor bijdraagt aan het ontwikkelen van psychische klachten, en mogelijk ook de uitval als gevolg hiervan.

Om (1) de omvang van en ontwikkelingen in werkdruk in Europa te beschrijven, en (2) Nederland op het gebied van werkdruk in Europa te positioneren, en (3) oorzaken van werkdruk in Europa te identificeren, wordt de European Working Conditions Survey (EWCS; http://www.eurofound.eu.int/working/surveys/index.htm) nader geanalyseerd. Deze EWCS is een onderzoek onder een representatieve steekproef werkenden uit de Europese Lidstaten dat periodiek wordt uitgevoerd in opdracht van de European Foundation for the Improvement of Living and Working Conditions (EFILWC, verder kortweg 'European Foundation' genoemd). We bespreken hierna dit bestand iets uitgebreider, bespreken vervolgens de werkdruk in Europa in het jaar 2000, en vergelijken de ontwikkelingen hierin voor de verschillende EUlidstaten tussen 1990 en 2000 . Deze landenvergelijking houdt tevens een positionering in van Nederland op het gebied van werkdruk. Tegelijk wordt gekeken naar de trends in regelmogelijkheden. Toch een van de belangrijkste factoren die samen met hoge taakeisen verondersteld wordt te leiden tot gunstige of juist minder gunstige werkdrukgevolgen (zie met name het DC-model).

Hierna worden oorzaken - wellicht is het beter om te spreken van 'verklaringen' - van verschillen in werkdruk geïdentificeerd, omdat we dat alleen kunnen onderzoeken op basis van weliswaar representatieve, maar 
crosssectionele steekproefgegevens van werkenden.

Naast de trends in werkdruk in Europa en de positionering van Nederland daarin beogen we in deze bijdrage werkdruk te verklaren uit zowel aspecten die te maken hebben met de inhoud en organisatie van werk, alsook met de privésituatie, waarbij tevens binnen subgroepen wordt geanalyseerd. Allereerst wordt er geanalyseerd naar sekse, in verband met de verschillende werkzaamheden, maar vooral in verband met het verschil in belasting door zorgtaken. Daarnaast wordt ook gekeken naar verschillen tussen witte en blauwe boorden, waarbij met name wordt gekeken of de verklaringen anders uitpakken voor werkenden in beroepen met en zonder zware fysieke belasting. Dit betekent dat rekening gehouden wordt met het fysiek zware werk dat zijn herstel eist, maar tevens specifiek binnen deze beroepsgroepen mogelijk ook met factoren in of buiten werk die hiermee kunnen samenhangen.

\section{Het gebruikte gegevensbestand}

Om de vragen van dit onderzoek te beantwoorden is gebruikgemaakt van gegevens uit de Europese Survey die de European Foundation over de afgelopen tien jaar driemaal heeft laten afnemen in alle Europese lidstaten van dat moment. In 1991/1992, $1995 / 1996$ en in 2000. Omdat er in 1991/1992 minder Europese lidstaten waren dan in 1995/1996, bevat het eerste bestand informatie uit slechts twaalf landen, terwijl de bestanden uit 1995/1996 en 2000 informatie over vijftien Europese lidstaten bevatten (Finland, Zweden en Oostenrijk zijn er in die periode bijgekomen).

Per land zijn telkens representatieve steekproeven uit de beroepsbevolking getrokken. In het eerste meetjaar zijn er per land gemiddeld 1000 face-to-face-interviews met werkenden gehouden (m.u.v. Luxemburg: $n=$ 500). Tijdens de twee volgende metingen waren het er 1.500 per land (Luxemburg $n=$ 750). Het totale gegevensbestand in 1991/ 1992 is gekomen op $n=12.819$, in 1995/1996 op $n=15.989$ en in 2000 op $n=21.703$.

Wat betreft de operationalisatie van begrippen, zowel van werkdruk als van mogelijke oorzaken voor werkdruk, zijn wij uiteraard gebonden aan de vragen die in deze Survey zijn meegenomen. Bij de operationalisatie van werkdruk zijn er twee vragen, één naar werktempo en één naar deadlines (tabel 1). In dit artikel is er sprake van werkdruk als iemand zegt meer dan $50 \%$ van de werktijd in een hoog tempo te moeten werken, dan wel dat hij met deadlines te maken heeft.

Omdat de operationalisatie van verschillende aspecten van werk- en niet-werkgebonden variabelen niet helemaal hetzelfde is geweest in de verschillende jaren, en omdat het aantal gemeten variabelen eigenlijk alleen is toegenomen in de loop der jaren, wordt de toets naar verklaringen van werkdruk alleen op het in 2000 verzamelde bestand uitgevoerd. In dat jaar zijn ook de meeste additionele vragen meegenomen.

In tabel 1 is een overzicht opgenomen van de gemeten variabelen en, indien het om een schaal gaat, met hun Cronbach's alfa.

Analyses om de oorzaken van werkdruk te identificeren zijn uitgevoerd voor alle werkenden, voor mannen en vrouwen, en voor de hoge en lage inkomens. Deze laatste vergelijking is tevens een poging om de tweedeling tussen blauwe en witte boorden te benaderen. Er is er hierbij van uitgegaan dat de hogere inkomens vooral werkenden in witteboordenfuncties betreft, en de lage inkomens vooral de werkenden in blauweboordenfuncties.

De variabele 'inkomen' is niet in tabel 1 opgenomen, maar is wel in de verklarende analyses gebruikt. Deze variabele is door de European Foundation bewerkt, wat enige toelichting behoeft. Het inkomen is nagevraagd, waarbij 12 inkomensklassen worden onderscheiden. Er bestaan echter grote verschillen tussen de inkomens in de verschillende EU-lidstaten. Om die reden heeft de Foundation het inkomen 'gehomogeniseerd', dat wil zeggen per land in kwartielen opgedeeld. Zo zit er van iedere EU-lidstaat een kwart van de beroepsbevolking in de hoge inkomensgroep, en een kwart in de lage inkomensgroep, terwijl de helft de middeninkomens vormt. In de analyses naar oorzaken voor werkdruk is de middengroep van inkomens buiten beschouwing gelaten, en zijn de oorzaken van werkdruk bij de meest contrasterende groepen, de hoge versus de lage inkomens, in kaart gebracht. 
Tabel 1 Gebruikte variabelen en hun operationalisatie

\begin{tabular}{|c|c|c|c|c|c|}
\hline Variabele & $\begin{array}{l}\text { Aantal } \\
\text { items }\end{array}$ & Items & $\begin{array}{l}\text { Score } \\
\text { range }\end{array}$ & Scoreberekening 3 & $\begin{array}{l}\text { Cronbach's } \\
\text { alfa }\end{array}$ \\
\hline $\begin{array}{l}\text { Werkdruk/kwantita- } \\
\text { tieve taakeisen }\end{array}$ & 2 & $\begin{array}{l}\text { Werken in hoog tempo, werken } \\
\text { met deadlines }\end{array}$ & $\begin{array}{l}1-7 \\
\text { altijd-nooit }\end{array}$ & $\begin{array}{l}0-4=100 \\
5-7=0\end{array}$ & .65 \\
\hline $\begin{array}{l}\text { Regelmogelijkheden/ } \\
\text { autonomie }\end{array}$ & 3 & $\begin{array}{l}\text { Vrij om de volgorde/methode/ } \\
\text { tempo te kiezen }\end{array}$ & $\begin{array}{l}1-2 \\
\text { ja-nee }\end{array}$ & $\begin{array}{l}1=0 \\
2=100\end{array}$ & .64 \\
\hline $\begin{array}{l}\text { Sociale steun van } \\
\text { leiding en collega's }\end{array}$ & 3 & $\begin{array}{l}\text { Assistentie/regelmatig } \\
\text { gesprekken met collega's } \\
\text { c.q. met baas }\end{array}$ & $\begin{array}{l}1-2 \\
\text { ja-nee }\end{array}$ & $\begin{array}{l}1=0 \\
2=100\end{array}$ & .77 \\
\hline $\begin{array}{l}\text { Kwalitatieve taakeisen/ } \\
\text { taakcomplexiteit }\end{array}$ & 6 & $\begin{array}{l}\text { Tegemoetkomen aan } \\
\text { kwaliteitsnormen/beoordelen } \\
\text { kwaliteit/problemen oplossen/ } \\
\text { monotonie/complex werk/ } \\
\text { nieuwe dingen leren }\end{array}$ & $\begin{array}{l}1-2 \\
\text { ja-nee }\end{array}$ & $\begin{array}{l}1=0 \\
2=100\end{array}$ & .74 \\
\hline Fysieke belasting & 3 & $\begin{array}{l}\text { Pijnlijke houding/zwaar werk/ } \\
\text { herhaalde bewegingen }\end{array}$ & $\begin{array}{l}1-7 \\
\text { altijd-nooit }\end{array}$ & $\begin{array}{l}(v 1+v 2+v 3-3) * \\
100 / 18\end{array}$ & 4.69 \\
\hline $\begin{array}{l}\text { Discriminatie op } \\
\text { het werk }\end{array}$ & 7 & $\begin{array}{l}\text { Confrontatie met fysiek geweld/ } \\
\text { intimidatie/discriminatie naar } \\
\text { leeftijd/ras/sekse/handicap } \\
\text { door collega's c.q. cliënten }\end{array}$ & $\begin{array}{l}1-2 \\
\text { ja-nee }\end{array}$ & $\begin{array}{l}1=100 \\
2=0\end{array}$ & .59 \\
\hline Arbeidstijden & 1 & Aantal uren gemiddeld per week & $\begin{array}{l}1-18 \\
\text { categorieën }\end{array}$ & $\begin{array}{l}1=0 \\
18=100 \\
\text { (gelijk verdeeld) }\end{array}$ & - \\
\hline Afwijkende werktijden & 5 & $\begin{array}{l}\text { 's nachts/'s avonds/meer dan } \\
10 \text { uur per dag/zaterdags/ } \\
\text { zondags }\end{array}$ & $\begin{array}{l}\text { aantal keer/ } \\
\text { maand }\end{array}$ & Zie links & .65 \\
\hline Thuis werken & 1 & Thuis werken & $\begin{array}{l}1-2 \\
\text { ja-nee }\end{array}$ & $\begin{array}{l}1=100 \\
2=0\end{array}$ & - \\
\hline $\begin{array}{l}\text { Werken met de } \\
\text { computer }\end{array}$ & 1 & Werken met computers & $\begin{array}{l}1-7 \\
\text { altijd-nooit }\end{array}$ & $\begin{array}{l}\text { (7-computer) } * \\
100 / 6 \\
\text { of: } \\
1=100 \\
7=0\end{array}$ & - \\
\hline Telewerken & 1 & Thuis werken met een computer & $\begin{array}{l}1-7 \\
\text { altijd-nooit }\end{array}$ & $\begin{array}{l}1=100 \\
7=0\end{array}$ & - \\
\hline Zorgtaken kinderen & 1 & $\begin{array}{l}\text { Betrokken bij zorg voor en } \\
\text { opvoeding van kinderen }\end{array}$ & $\begin{array}{l}1-2 \\
\text { ja-nee }\end{array}$ & $\begin{array}{l}1=100 \\
2=0\end{array}$ & - \\
\hline Zorgtaken anderen & 1 & Zorg voor ouderen & $\begin{array}{l}1-2 \\
\text { ja-nee }\end{array}$ & $\begin{array}{l}1=100 \\
2=0\end{array}$ & - \\
\hline $\begin{array}{l}\text { Verantwoordelijk voor } \\
\text { huishoudelijke taken }\end{array}$ & 3 & $\begin{array}{l}\text { Koken/huishoudelijk werk/ } \\
\text { boodschappen }\end{array}$ & $\begin{array}{l}1-2 \\
\text { ja-nee }\end{array}$ & $\begin{array}{l}1=100 \\
2=0\end{array}$ & .83 \\
\hline
\end{tabular}

De omvang en ontwikkelingen van werkdruk in Europa van 1991-2000

\section{Ontwikkelingen in werkdruk}

In figuur 1 en 2 staan de metingen weergegeven van het percentage werkenden dat minimaal de helft van de werktijd met een hoog werktempo of met strakke deadlines heeft moeten werken. In deze figuren is te zien dat werkdruk in de EU over het laatste decennium gestaag is gestegen. We zien dat terug in de antwoorden op beide vragen die in de Survey over werkdruk worden gesteld. Figuur
2 geeft de trend over 1991/1992 tot 2000 voor de vijftien EU-lidstaten aan. In 2000 staat Zweden aan kop, op de voet gevolgd door Nederland, Finland en Engeland. 
Werkdruk in Europa: omvang, ontwikkelingen en verklaringen

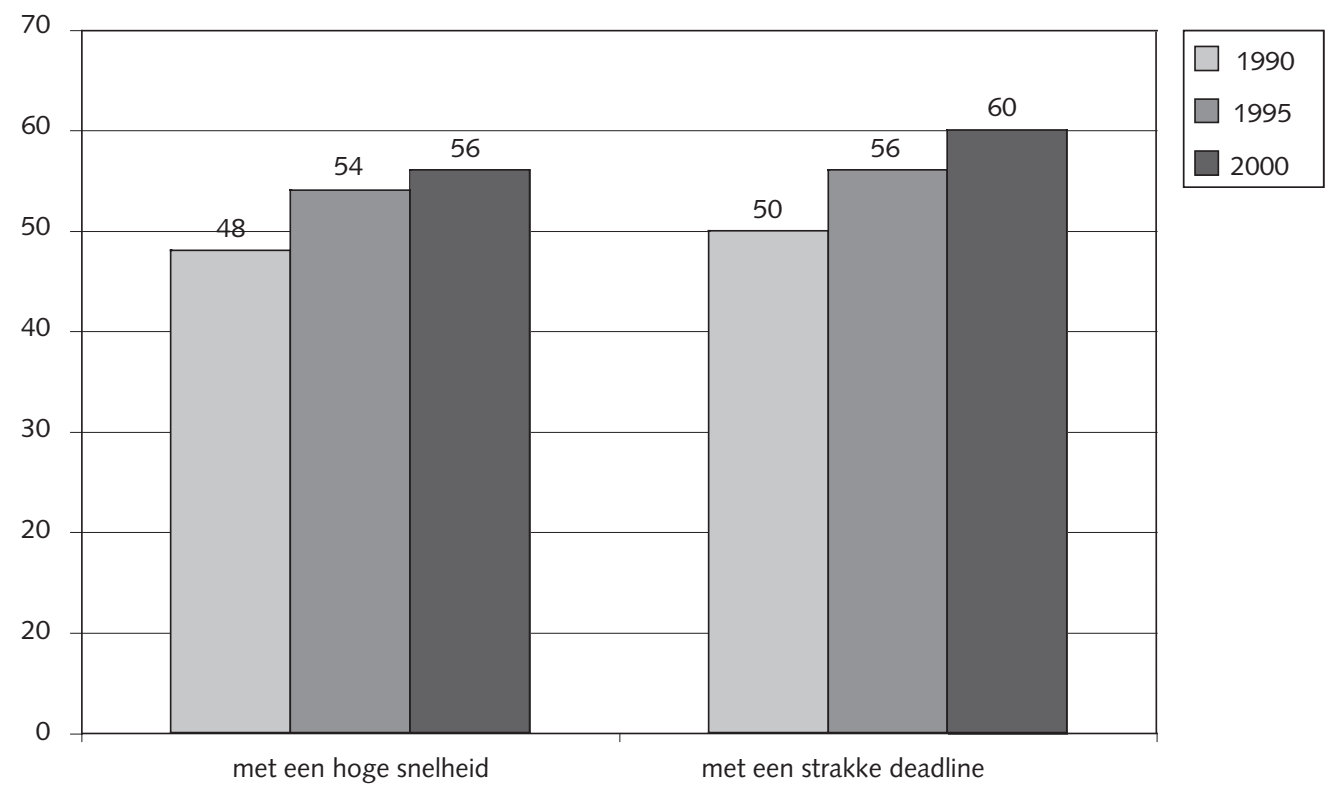

(\% werknemers dat minimaal $50 \%$ van werktijd onder werkdruk werkt)

Figuur 1 Percentage werkenden in Europa dat minimaal 50 procent van de tijd in een hoog tempo werkt of met strakke deadlines werkt (1990-2000; bron: EFILWC, in 1990 is het EU-gemiddelde gebaseerd op 12 Europese lidstaten)

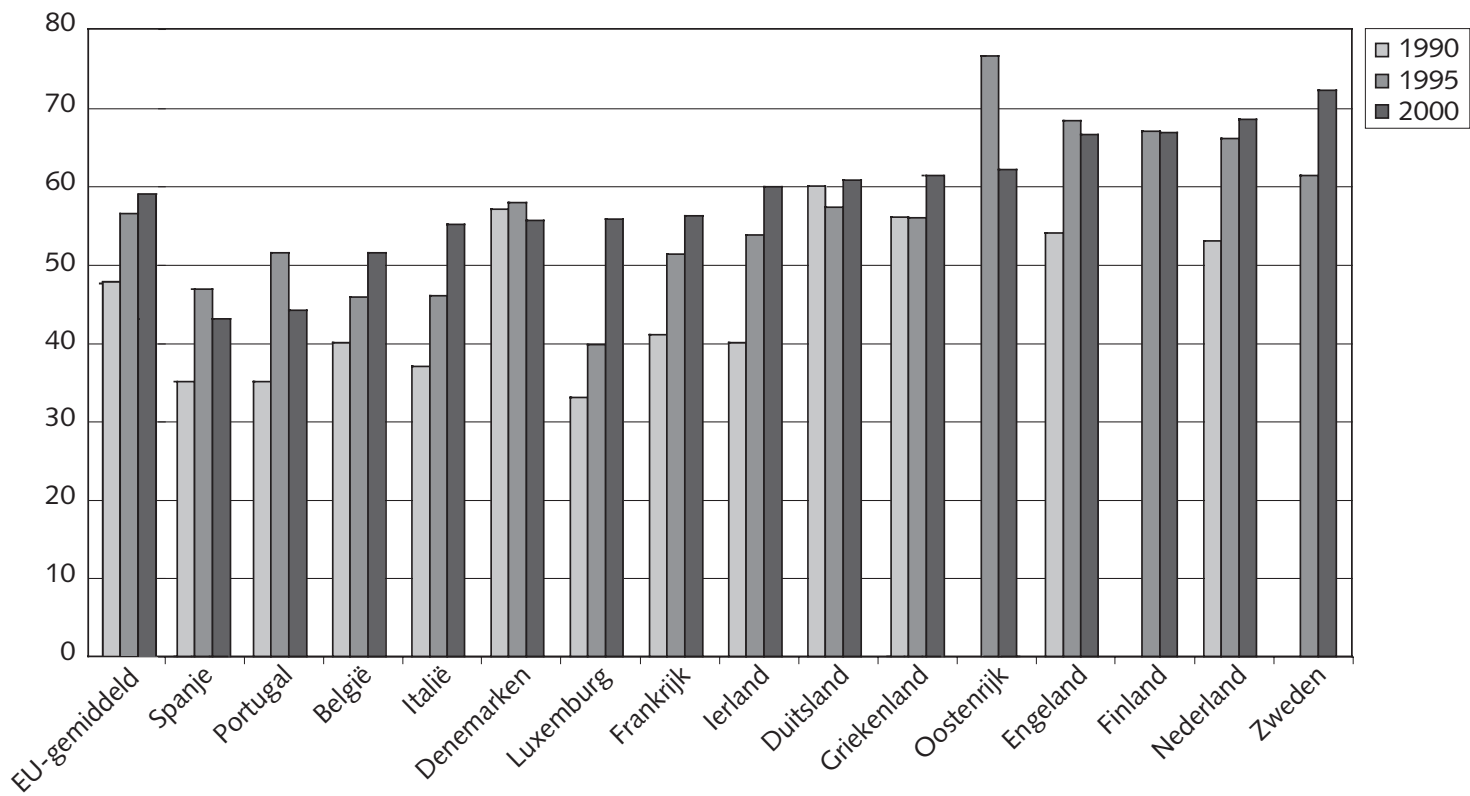

Figuur 2 Percentage werkenden in Europa dat minimaal 50 procent van de tijd in een hoog tempo werkt, dan wel met strakke deadlines te maken heeft, uitgesplitst naar land (1990-2000; bron: EFILWC) 
We zien dat de stijging van werkdruk in Europa vooral in de periode tussen 1990 en 1995 heeft plaatsgevonden. In de tweede helft van de jaren negentig is de stijging nog wel significant, maar veel geringer. Deze ontwikkeling zien we ook in de landen met een hoge werkdruk, waaronder Nederland. Vanwege het geringere aantal werkenden is de stijging in werkdruk in Nederland over de periode 1995-2000 niet meer significant. Dit is in overeenstemming met de ontwikkelingen in de nationale statistieken van het CBS (o.a. Houtman et al., 2001).

\section{Ontwikkelingen in regelmogelijkheden}

Theoretische modellen, zoals het DemandControl(-Support) Model (Karasek \& Theorell, 1990) benadrukken dat werkdruk, het worden blootgesteld aan hoge taakeisen, op zichzelf niet gezondheidsbedreigend is. Het is vooral de combinatie met onvoldoende regelmogelijkheden in het werk die leidt tot allerlei gezondheidsproblemen. Vanuit het sociotechnische gedachtegoed zijn het zelfs de gebrekkige regelmogelijkheden die (mede) een hoge werkdruk veroorzaken (o.a. Vaas et al., 1995; Christis, 1998). Om die reden is het tevens interessant om te zien hoe deze regelmogelijkheden in het werk zich hebben ontwikkeld, en waar Nederland zich op dat punt positioneert.

De ontwikkeling in regelmogelijkheden in Europa laat over de periode van 1990 tot en met 2000 een grillig verloop zien (Paoli \& Merllié, 2001). Op hoofdlijnen is over deze periode een toename van regelmogelijkheden te zien, maar dat is vooral het geval geweest over de periode 1991-1995. In de periode 1995-2000, toen er ook sprake was van een afvlakking van de werkdruk, blijkt er ook sprake te zijn van een lichte afname van de regelmogelijkheden. Omdat in 1991/1992 wat andere vragen zijn gebruikt bekijken we met name de ontwikkeling van 1995 tot 2000. In figuur 3 is deze ontwikkeling in regelmogelijkheden voor de werkenden uit de 15 EUlidstaten weergegeven. In die landen waar weinig problemen op dit gebied bestonden, zijn de regelmogelijkheden over de periode van 1995 tot 2000 wat toegenomen, en in die landen waar 'regelmogelijkheden' meer een probleem waren is dit probleem in het algemeen afgenomen, met name in Portugal.

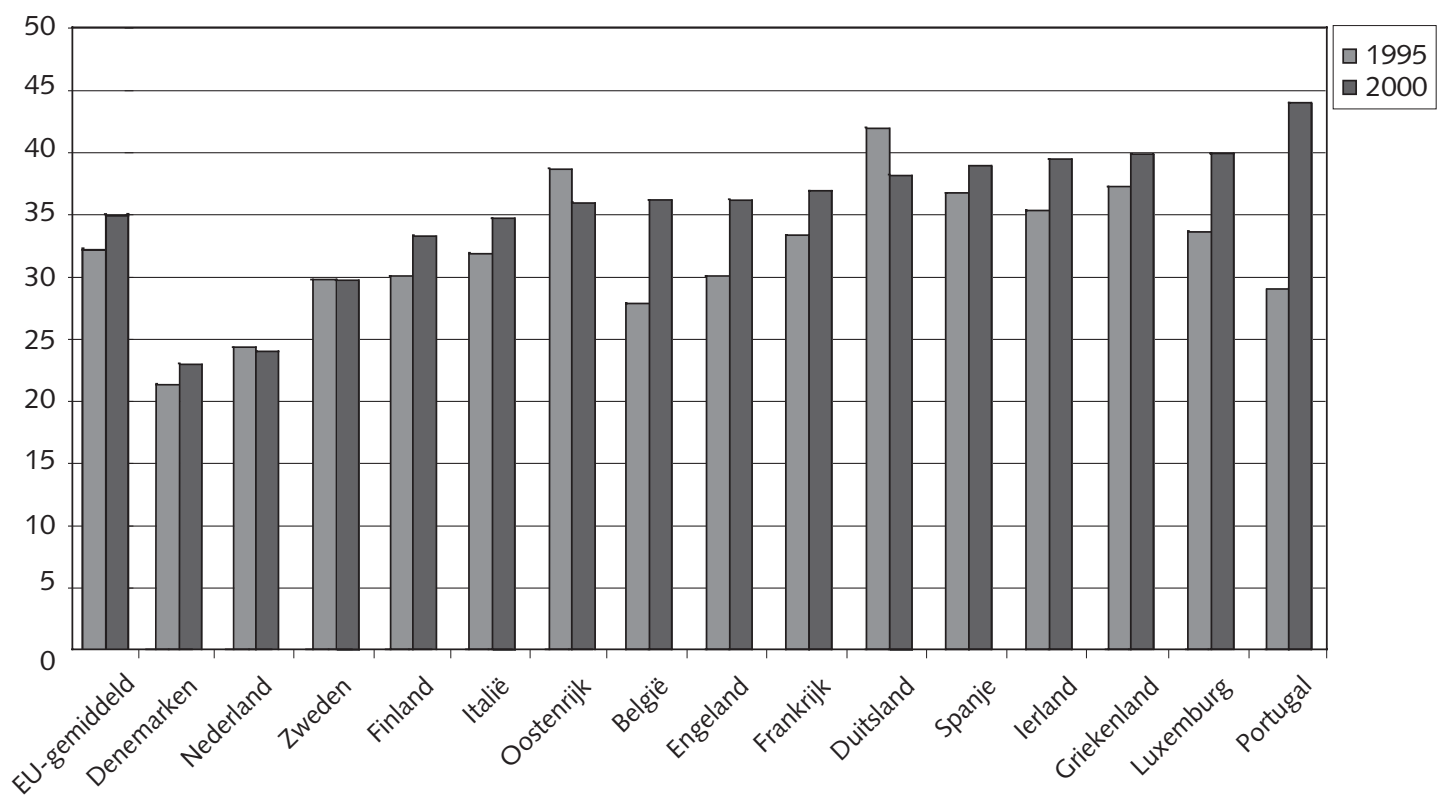

Figuur 3 Gemiddeld percentage werkenden in Europa dat zegt gebrekkige regelmogelijkheden te hebben over de periode 1995/6-2000 (bron: EFILWC) 
Het Demand-Control(-Support) Model (DCSmodel; Karasek \& Theorell; 1990) veronderstelt dat de kwantitatieve taakeisen of werkdruk en regelmogelijkheden in het werk hoofddimensies van werkstress zijn, waarbij hoge taakeisen vooral in combinatie met weinig regelmogelijkheden negatieve gevolgen hebben voor de gezondheid. Hoge taakeisen gecombineerd met veel regelmogelijkheden duiden op uitdagend werk, waarbij men waarschijnlijk wel moe maar ook voldaan is. Op termijn zou deze combinatie niet tot negatieve gezondheidsgevolgen leiden, maar de werknemers in hun werk laten groeien. De landelijke scores op deze twee dimensies zijn in figuur 4 naar land tegen elkaar uitgezet. Op basis hiervan is te zien dat het werk van Nederlandse werknemers als uitdagend kan worden getypeerd: de Nederlander werkt dan weliswaar onder een hoge werkdruk, gemiddeld genomen staan daar relatief veel regelmogelijkheden in het werk tegenover.

\section{Oorzaken van werkdruk}

Om na te gaan wat in Europa de belangrijkste oorzaken van werkdruk zijn, is ervoor gekozen een regressieanalyse uit te voeren met werkdruk als afhankelijke variabele. Deze analyse is uitgevoerd op het bestand dat in 2000 is verzameld. Dit omdat dit bestand niet alleen het meest recent is, maar ook omdat het de meeste informatie over de werksituatie en de niet-werksituatie bevat.

Voorafgaand aan de regressieanalyse is een overzicht gemaakt van de gemiddelde scores van de gebruikte variabelen (of het percentage werkenden dat ' $\mathrm{ja}$ ' op de betreffende vraag heeft geantwoord), hun spreiding en onderlinge samenhang. Dit geeft inzicht in de wijze waarop de variabelen crosssectioneel en univariaat samenhangen (tabel 2). Vanwege het grote aantal respondenten zijn nagenoeg alle correlaties significant. Veel correlaties zijn daarentegen niet relevant. Als vuistregel kan worden gehanteerd dat samenhangen die $r=$ 0,10 of hoger zijn interessant gaan worden.

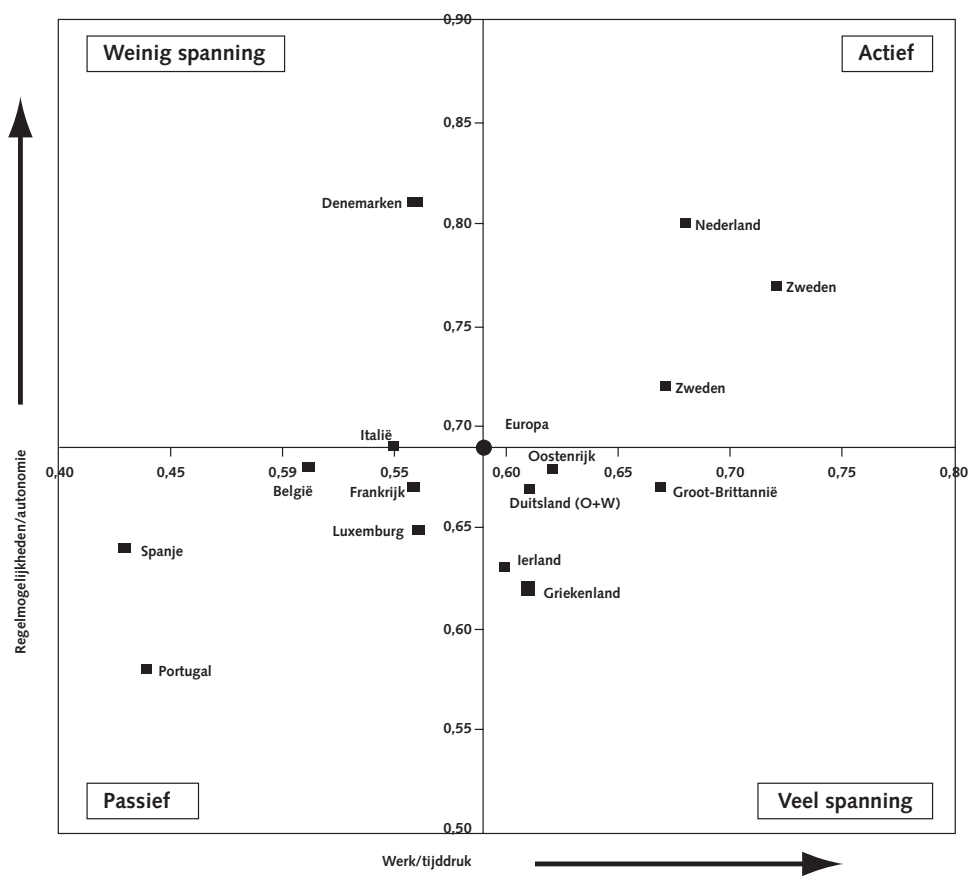

Figuur 4 Plaatsing van de 15 EU-landen uit het jaar 2000 op resp. Werkdruk/tijdsdruk en Regelmogelijkheden/autonomie (beide op een gestandaardiseerde schaal van 0-1.00; bron: EFILWC, 2000) 


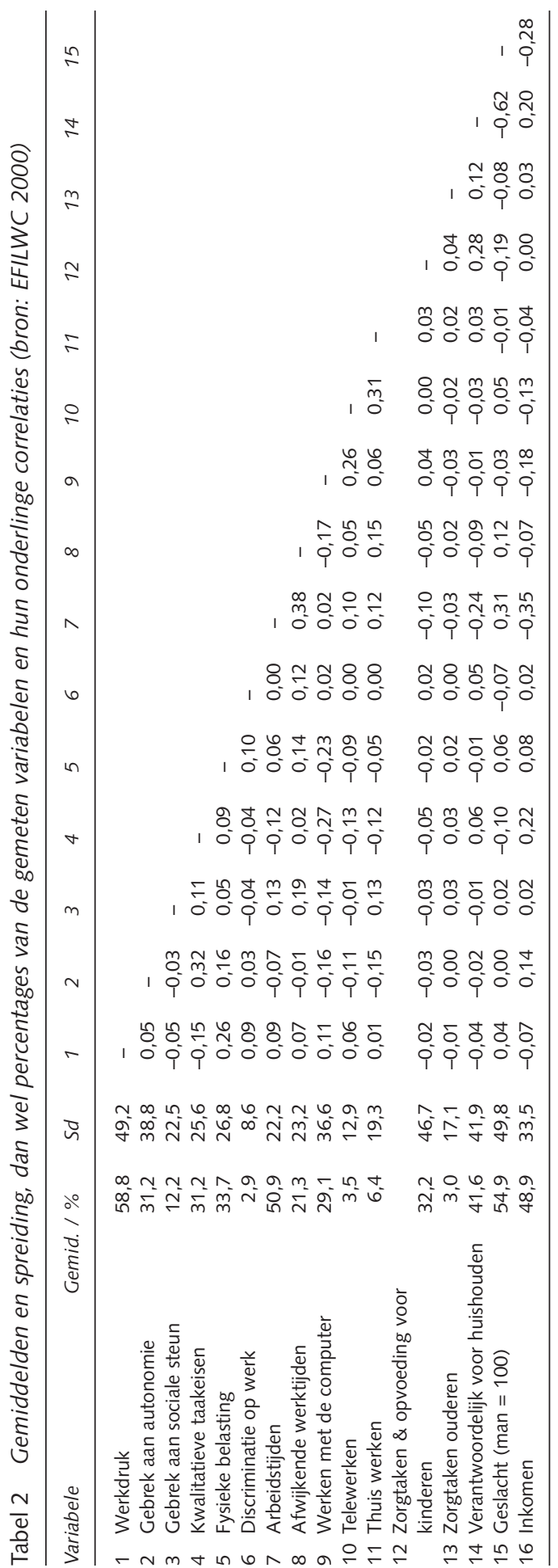

De regressieanalyse op werkdruk is stapsgewijs uitgevoerd. In de eerste stap zijn de variabelen sekse en leeftijd als controle variabelen ingevoerd. In een tweede stap zijn de werkvariabelen ingevoerd, en in de laatste stap zijn de niet-werkgebonden risico's ingevoerd, waaronder zorg voor kinderen, ouderen en huishouden.

Uit de regressieanalyses blijkt dat de drie stappen afzonderlijk een significante bijdrage leveren aan de verklaring van verschillen in werkdruk. Er wordt in het totaal echter slechts $12 \%$ van de variantie in werkdruk verklaard. Dat is betrekkelijk weinig.

Significante bijdragen aan de verklaring van werkdruk zijn opgenomen in tabel 3. Er zijn veel bijdragen significant, maar de meeste zijn vooral significant vanwege het grote aantal respondenten en hebben slechts een geringe bijdrage. Ook hier kunnen we voor de regressiegewichten als vuistregel de grenswaarde van 0,10 gebruiken. In dat geval draagt zo'n variabele circa $3 \%$ (of bij een hogere regressiecoëfficiënt meer) bij aan de verklaring van werkdruk.

Net als in de analyses van Wiezer en anderen (2005) zijn het vooral aspecten van arbeidsinhoud zoals kwalitatieve taakeisen/complexiteit en vooral de fysieke taakeisen die in zekere mate kunnen worden gezien als 'oorzaak' of verklaring van werkdruk. Zo hangt een hoge mate van fysieke belasting samen met veel werkdruk, maar hangen opvallend hoge kwalitatieve taakeisen samen met weinig werkdruk in de totale populatie. Daarnaast draagt het werken met de computer bij aan hoge werkdruk.

\section{Man-vrouwverschillen}

Net als in de totale beroepsbevolking zijn fysieke belasting en kwalitatieve taakeisen voor zowel mannen als vrouwen belangrijke verklarende factoren van werkdruk. Interessant is daarnaast om te zien dat juist bij de mannen, die gemiddeld veel meer uren per week werken dan vrouwen, het aantal gewerkte uren in belangrijke mate de verschillen in werkdruk verklaart. Bij vrouwen zijn de werktijden wat minder van belang. 
Werkdruk in Europa: omvang, ontwikkelingen en verklaringen

Tabel 3 Resultaten van de regressieanalyse met werkdruk als afhankelijke variabele, bij totaal en vier subgroepen (uitgedrukt in bètacoëfficiënten)

\begin{tabular}{llllll}
\hline Variabele & $\begin{array}{l}\text { Totaal } \\
(n=22703)\end{array}$ & $\begin{array}{l}\text { Mannen } \\
(n=11906)\end{array}$ & $\begin{array}{l}\text { Vrouwen } \\
(n=9797)\end{array}$ & $\begin{array}{l}\text { Hoog inkomen } \\
(n=3960)\end{array}$ & $\begin{array}{l}\text { Laag inkomen } \\
(n=3600)\end{array}$ \\
\hline Geslacht & $\mathrm{ns}$ & - & - & $\mathrm{ns}$ & $\mathrm{ns}$ \\
Leeftijd & -.04 & -.06 & -.03 & -.06 & -.07 \\
Gebrek aan regelmogelijkheden & .05 & .05 & .07 & $\mathrm{~ns}$ & .08 \\
Gebrek aan sociale steun & -.04 & -.04 & -.06 & -.04 & -.06 \\
Taakcomplexiteit & -.13 & -.13 & -.14 & .12 & -.13 \\
Fysieke belasting & .28 & .27 & .29 & .23 & .31 \\
Discriminatie op het werk & .03 & .03 & .04 & .04 & $\mathrm{~ns}$ \\
Arbeidstijden & .06 & .08 & .04 & .07 & $\mathrm{~ns}$ \\
Afwijkende werktijden & .04 & .04 & .04 & $\mathrm{~ns}$ & .05 \\
Werken met de computer & .13 & .11 & .14 & .11 & .09 \\
Telewerken & .04 & .05 & $\mathrm{~ns}$ & $\mathrm{~ns}$ & $\mathrm{~ns}$ \\
Thuis werken & $\mathrm{ns}$ & $\mathrm{ns}$ & $\mathrm{ns}$ & .05 & $\mathrm{~ns}$ \\
Zorgtaken kinderen & -.02 & $\mathrm{~ns}$ & $\mathrm{~ns}$ & -.04 & $\mathrm{~ns}$ \\
Zorgtaken ouderen & $\mathrm{ns}$ & $\mathrm{ns}$ & $\mathrm{ns}$ & $\mathrm{ns}$ & $\mathrm{ns}$ \\
Verantwoordelijk huishouden & $\mathrm{ns}$ & $\mathrm{ns}$ & $\mathrm{ns}$ & $\mathrm{ns}$ & $\mathrm{ns}$ \\
Verklaarde variantie & $12 \%$ & $11 \%$ & $14 \%$ & $10 \%$ & $15 \%$ \\
\hline
\end{tabular}

* De middengroep met een middeninkomen $(n=9288)$ is hierbij uitgesloten.

Het kunnen telewerken is alleen bij mannen een significant verklarende factor voor werkdruk: telewerken hangt bij hen samen met een hogere werkdruk. Bij vrouwen is 'telewerken' geen significante oorzaak van werkdruk. Dit suggereert dat telewerken vooral moet worden geassocieerd met negatieve gevolgen zoals het verdwijnen van de afgrensbaarheid van werk en privé, en minder met positieve gevolgen zoals het vergemakkelijken van het combineren van werk en privé.

\section{Hoge versus lage inkomens}

Ook zijn er analyses uitgevoerd voor mensen met een hoog, dan wel met een laag inkomen. In deze dichotomie zitten blauwe boorden vooral in de functies met lage inkomens, terwijl de witte boorden vooral in de hoger betaalde functies voorkomen. Allereerst valt op dat werkdruk bij de lagere inkomens beter wordt verklaard door de in de analyse meegenomen variabelen dan bij de hogere inkomens. Dit komt waarschijnlijk vooral doordat met name bij de lagere inkomens de fysieke belasting een bijna alles bepalende invloed heeft (zie tabel 3). Ook hier weer draagt de complexiteit van het werk bij aan de verklaring van werkdruk. Opvallend is hier echter dat bij lage inkomens complex en moeilijk werk samengaat met een lage werkdruk, ter- wijl dit bij hogere inkomens juist samenhangt met een hogere werkdruk. Dit suggereert bijna dat de (beantwoording van) vragen naar de moeilijkheid van het werk in deze Survey nogal gevoelig zijn voor het inkomensniveau en misschien ook samenhangen met verschillen in opleidingsniveau van de werkenden in kwestie. Het kan ook zijn dat met name bij de lage inkomens lage scores op de vragen over moeilijkheid van het werk samenhangen met juist heel simpel en monotoon werk en de relatie moet worden geïnterpreteerd als dat het simpele, monotone werk bij lage inkomens gepaard gaat met het ervaren van een hoge werkdruk.

Bij de lage inkomens is, in tegenstelling tot bij de hoge inkomens, het belang van werken met de computer als verklaring voor werkdruk nagenoeg afwezig. Dit komt waarschijnlijk doordat zoals verondersteld het werken met de computer bij diegenen met een laag inkomen weinig voorkomt. Bij de hogere inkomens verklaart het hebben van zorgtaken voor kinderen, evenals het kunnen thuiswerken een klein beetje de werkdruk, maar bij de lagere inkomens niet. Het hebben van zorgtaken voor kinderen gaat dan echter gepaard met een lagere werkdruk. 


\section{Conclusies en discussie}

In deze bijdrage is geprobeerd inzicht te krijgen in (1) de omvang van en ontwikkelingen in werkdruk in Europa, (2) Nederland op het gebied van werkdruk in relatie tot de rest van Europa, en (3) de oorzaken van werkdruk in Europa. Hiertoe is het door de European Foundation verzamelde gegevensbestand over de periode 1991 tot en met 2000 opnieuw geanalyseerd.

\section{De ontwikkeling van werkdruk en de positione- ring van Nederland op werkdruk}

Wat de omvang van werkdruk betreft moet worden geconstateerd dat anno 2000 gemiddeld bijna 60 procent van de werkenden in Europa minstens de helft van de werktijd in een hoog tempo werkt en/of regelmatig met deadlines wordt geconfronteerd. Dat is veel. Opvallend is daarnaast dat Nederland op dit aspect al jaren ver boven het Europees gemiddelde scoort: in Nederland rapporteert 68 procent van de werkenden minstens de helft van de werktijd in een hoog tempo te werken en/of regelmatig met deadlines te worden geconfronteerd. Werkenden in Nederland kunnen zich op het gebied van werkdruk gesteund voelen door werkenden in Zweden, Finland, Engeland en Oostenrijk. In deze landen wordt eveneens een hoge werkdruk gerapporteerd. Deze landen zijn ook de landen, wellicht met uitzondering van Engeland, waar werkenden in het algemeen ook veel regelmogelijkheden in het werk hebben. Op basis van de combinatie van deze twee kenmerken - namelijk veel kwantitatieve taakeisen en ook veel regelmogelijkheden - kan worden geconcludeerd dat werkenden in Nederland, Zweden en Finland hun werk uitdagend vinden. Uitdagend werk, met veel eisen en veel regelmogelijkheden, leidt volgens het DCS-model tot gevoelens van beheersing en 'mastery'. Wanneer dat beklijft, remt het de kans om in een situatie van overbelasting, van 'strain' te komen. Stressvol werk wordt daarentegen gekenmerkt door een combinatie van hoge takeisen en weinig regelmogelijkheden, en deze combinatie werkt volgens het DCS-model remmend op leergedrag. Werkenden in Griekenland, het Verenigd koninkrijk (UK), Oostenrijk en Duitsland ervaren het werk in vergelijking tot de werkenden in de andere Europese lidstaten als 'stressvol'. Het werk in landen als Portugal en Ierland wordt door de werkenden als relatief 'saai' gekenschetst.

We moeten daarnaast constateren dat de werkdruk in Europa, evenals in Nederland in de periode 1990-2000 is gestegen. Er kan dan ook worden geconcludeerd dat werkdruk niet een typisch Nederlands probleem is. Het speelt in veel landen, vooral in Noord- en Midden-Europa. Opmerkelijk is dat deze stijging in werkdruk in veel landen gepaard gaat met minder regelmogelijkheden (ofwel een groter gebrek aan regelmogelijkheden). Dat is niet in alle landen het geval. In Nederland en Zweden, landen waar de werkdruk tot de hoogste van Europa behoort, is sprake van een stabilisatie, en in Oostenrijk zelfs van een toename in regelmogelijkheden. De vele regelmogelijkheden in deze landen maken de hoge taakeisen daarmee tot een minder groot risico. De typering langs de hoofddimensies van het DCS-model krijgt vooral recentelijk toch wel enige kritiek. Behalve het feit dat het hier om een relatieve positionering gaat, is er weinig onderzoek gedaan naar de effecten van andere dimensies dan stressvol werk. Onlangs is enig onderzoek gedaan naar de langeretermijngevolgen van uitdagend werk. In een recent longitudinaal onderzoek onder docenten kon de hypothese dat uitdagend werk het leergedrag stimuleert en niet tot overbelasting leidt, niet worden bevestigd (Taris et al., 2003). Taris en collegae vonden juist dat ontspannen, nietactieve banen met weinig eisen en veel regelmogelijkheden tot leren aanzetten, terwijl docenten in actieve banen, banen met veel eisen maar ook veel regelmogelijkheden, in het daaropvolgende jaar juist de meeste gezondheidsklachten rapporteerden.

De wijze waarop eisen en regelmogelijkheden elkaar, in de tijd en in verschillende combinaties, onderling beïnvloeden alsmede de effecten hiervan op diverse uitkomstmaten zijn nog onvoldoende onderzocht. Het onderzoek dat tot nu toe is gedaan mist veelal de volle breedte van de beroepsbevolking. Ook het onderzoek van Taris en anderen (2003) betrof slechts één beroepsgroep. Er is bovendien geen eenduidigheid over het optimale tijdsinterval om de relatie tussen arbeidsrisico's en gevolgen te bestuderen (o.a. De Lange, 2005). De typering van werkdruk op Europees of ook 
nationaal niveau kan daarnaast ook misleidend zijn, aangezien de trends op sectorniveau verschillend blijken (zie ook Houtman, 2005). Dit kan te maken hebben met de aan- of afwezigheid van verschillende risico's in bepaalde sectoren. Zo hebben werkenden in witteboordenfuncties weinig fysiek zwaar werk, al zullen zij wel veel statisch belast kunnen zijn door het langdurig in eenzelfde houding (zittend) werken. Ook zijn sommige sectoren wat gevoeliger voor economische veranderingen dan andere sectoren, waardoor bijvoorbeeld eerder, of een grotere mate van onderbezetting - en een toename van werkdruk - optreedt tijdens economisch minder gunstige tijden. Deze zijn er recentelijk zeker geweest, hoewel de recessie in sommige landen meer voet aan de grond heeft gekregen dan in andere. Specifiek voor Nederland geldt daarnaast nog dat in de periode vanaf eind jaren negentig in veel sectoren met een hoge werkdruk sectorbrede arboconvenanten zijn afgesloten, en veel inspanningen zijn gepleegd om werkdruk aan te pakken. Een eerste analyse van deze arboconvenanten laat zien dat de aanpak succesvol lijkt te zijn geweest (Veerman et al., 2004). Al deze verschijnselen kunnen deels verantwoordelijk zijn (geweest) voor verschillen in (trends in) werkdruk tussen landen en/of sectoren, zoals die binnen Europa kunnen worden gevonden (Houtman, 2005).

\section{De oorzaken van werkdruk}

Bij het beantwoorden van de vraag naar de oorzaken van werkdruk is het gebrek aan longitudinale databases een groot probleem. Ook in dit onderzoek kunnen geen causale relaties worden aangetoond, omdat we weliswaar naar trends kunnen kijken in de tijd, maar desalniettemin alleen de beschikking hebben over crosssectionele gegevens van werkenden in Europa. Bevindingen kunnen nu niet worden geïnterpreteerd als dat hoge fysieke en kwalitatieve taakeisen ook daadwerkelijk leiden tot het ervaren van een hoge werkdruk. We kunnen op basis van de nu uitgevoerde analyses echter alleen vaststellen dat er sprake is van een samenhang. De causale relatie zou eveneens kunnen zijn dat de fysieke belasting en complexiteit van het werk evenals het werken met de computer tot een geringer herstel leiden, dat op zijn beurt tot een geringere belastbaarheid leidt en vervol- gens tot (de perceptie van) een hoge werkdruk. Zowel de mening van werkenden over hun arbeidsomstandigheden, als ook de rapportage van met name psychische gevolgen als emotionele uitputting en depressieve klachten blijken ten slotte behoorlijk stabiel (Proper et al., 1999).

De analyses die in het kader van dit artikel zijn uitgevoerd met betrekking tot het Europese bestand om oorzaken van werkdruk te identificeren, hebben een aantal interessante verbanden laten zien, maar ook vragen opgeroepen over hoe dit nu precies te interpreteren. De in dit onderzoek verklaarde variantie in werkdruk was gering, en beduidend geringer dan die gevonden door Smulders en Houtman (2004), maar vergelijkbaar met die gevonden door Wiezer en anderen (2005). Net als uit de analyses van die onderzoeken bleek een belangrijke conclusie te zijn dat fysieke, cognitieve en emotionele taakeisen belangrijke verklaringen bleken voor het ervaren van een hoge werkdruk. Het onderzoek van Wiezer en anderen (2005) liet zien dat de relatie tussen fysieke belasting en werkdruk niet 'wegverklaard' werd door onderbezetting, zodat het daadwerkelijk de fysieke belasting, of wellicht de hersteltijd daarna is, die ook van invloed is op de ervaren werkdruk.

Andere belangrijke werkgebonden verklaringen voor werkdruk uit de Nederlandse studies, zoals de voorspelbaarheid van het werk en de mate en kwaliteit van de flexibilisering konden echter niet worden meegenomen als voorspeller van werkdruk.

De specifieke bijdrage van het hier nader geanalyseerde bestand was dat behalve het Europese karakter een aantal niet-werkgebonden, en deels ICT-gebonden activiteiten waar ook buiten het werk om mee kon worden gewerkt, als variabelen waren meegenomen. Het bleek niet alleen dat vooral het werken met de computer samenhing met een grotere werkdruk. Het leverde vooral een significante bijdrage aan werkgebonden vermoeidheid bij mannen en vrouwen, alsook bij de hogere inkomens, maar niet bij de lage inkomens. Mogelijk omdat het daar niet veel voorkomt. Veel van de effecten van het thuis werken (telewerken), of het combineren van werk en privé, bleken te verklaren vanuit man-vrouwverschillen, dan wel verschillen in inkomsten. 
De privéfactoren zijn op de totale groep van werkenden niet significant, maar er is wel sprake van een geringe bijdrage aan de verklaring van werkdruk. Wellicht omdat mannen een veel langere werkweek hebben dan vrouwen, draagt een lange(re) werkweek bij mannen wel bij aan de verklaring van een hoge werkdruk, maar bij vrouwen veel minder. Telewerken draagt daarbij opvallend genoeg bij mannen bij aan een hogere werkdruk, maar niet bij vrouwen. Dit laatste suggereert dat telewerken vooral bij mannen geassocieerd is met eventuele negatieve effecten van een verdwijnende grens tussen werk en privé, maar minder bij vrouwen. Telewerken blijkt overigens in het algemeen duidelijk geassocieerd te worden met 'werken met de computer' ( $r=.26$; tabel 2).

Telewerken noch zorgtaken dragen bij vrouwen bij aan werkdruk. Het lijkt er dus niet op dat telewerken het combineren van werk en privé vergemakkelijkt bij vrouwen (noch bij mannen).

Wanneer we de factoren bekijken die werkdruk bij werkenden met een hoog of een laag inkomen verklaren, valt ook een aantal verschillen op. Zo zien we enerzijds dat de taakcomplexiteit bij hogere inkomens bijdraagt aan de verklaring van de ervaren werkdruk, terwijl taakcomplexiteit juist een negatieve relatie heeft met werkdruk voor de lage inkomens. Dit komt waarschijnlijk doordat we de antwoorden op deze vragen door de lage inkomens wat anders moeten interpreteren, en deze relatie wellicht aangeeft dat mensen met lage inkomens simpel en monotoon werk doen, dat op zich samenhangt met een hoge werkdruk binnen deze groep.

Opvallend is verder dat het hebben van zorgtaken voor kinderen bij hoge inkomens samenhangt met een lage werkdruk. Hieraan kan een ingewikkelde interactie met werktijden en inkomen ten grondslag liggen, aangezien het aantal uren werk positief samenhangt met werkdruk, maar mensen die de zorg voor kinderen hebben, hebben vaak een kortere arbeidsweek $(r=-.10)$. Onder de groep werkenden met zorg voor kinderen valt een hele grote groep vrouwen. Velen van hen werken parttime, juist om de zorg voor kinderen met werk te kunnen combineren. Hoewel er mannen zijn die in deeltijd zijn gaan werken om ook voor hun kinderen te gaan zorgen, zijn ze veruit in de minderheid.
Heeft het signaleren van de oorzaken in dit onderzoek nog consequenties voor de aanpak van werkdruk? De huidige resultaten suggereren tenslotte dat een deel van de werkdruk kan worden verminderd door de fysieke werkbelasting te verminderen, het werk minder complex, maar wel 'interessant' te laten zijn, of te adviseren minder de computer te gebruiken. Het zal echter lang niet altijd mogelijk zijn om de fysieke belasting te verminderen, het werk interessant te maken en de computer te laten staan. Het bovenstaande geeft daarnaast ook aan dat de verbanden wel eens indirect zouden kunnen zijn, en dat ook de ontwikkelingen binnen de samenleving als geheel mede oorzaak kunnen zijn van de hoge werkdruk. Het onderzoek geeft ook aan dat oorzaken van werkdruk enigszins kunnen verschillen naar subgroep op de arbeidsmarkt. Een gedifferentieerde aanpak is geboden.

Samenvattend kan worden geconcludeerd dat:

- de omvang van het aandeel van werkenden die minstens de helft van de werktijd in een hoog tempo werken en/of met deadlines worden geconfronteerd hoog is. Zowel in Europa $(59 \%)$, als in Nederland, waar de werknemer tot de werkdruktoppers behoort (68\%). Met veel van deze toppers geniet de Nederlandse werknemer overigens wel relatief veel regelmogelijkheden in het werk, zodat het werk in Nederland, vergeleken met dat in andere landen als uitdagend kan worden getypeerd. Zowel in Nederland als in Europa was in de eerste helft van de jaren negentig een sterke stijging van werkdruk te zien en een geringe stijging in de tweede helft;

- oorzaken van werkdruk enerzijds moeten worden gezocht in de fysieke taakeisen en de taakcomplexiteit. Daarnaast draagt ook het werken met de computer bij aan het ervaren van werkdruk. Wanneer de gegevens worden uitgesplitst naar subgroepen op de arbeidsmarkt, zoals naar sekse en naar inkomen, blijken ook andere verklaringen aanwezig voor hoge werkdruk. Deze bieden aanknopingspunten om werkdruk specifiek aan te kunnen pakken. De resultaten van dit onderzoek dragen echter vooral bij aan diverse vragen over oorzaken van werkdruk, in het bijzonder in de subgroe- 
pen, die bij voorkeur aan de hand van longitudinaal onderzoek moeten worden onderbouwd, deze zijn:

- In hoeverre mediëren vermoeidheid en onvoldoende herstel het gevonden verband tussen fysieke werkbelasting en moeilijkheid van het werk enerzijds, en de ervaren werkdruk anderzijds?

- Is werken met de computer daadwerkelijk de oorzaak voor meer werkdruk, of is het toch de afnemende afgrensbaarheid van werk en privé die vooral bij mannen een belangrijke rol lijkt te spelen?

- Draagt telewerken ook bij aan de hoge werkdruk? Er is geen bewijs voor het feit dat het de zorg voor kinderen en het combineren van werk en privé vergemakkelijkt.

- Draagt interessant werk bij aan een vermindering van de werkdruk? Met name bij werkenden met een hoog inkomen overheersen de eisen die interessant werk met zich meebrengt, wat resulteert in een hogere werkdruk. De relatie tussen kwalitatieve eisen en werkdruk is derhalve het beste te schetsen als een kromlijnig verband: te weinig is niet goed, maar te veel ook niet.

- Is zorgtaken hebben voor kinderen een probleem? Dit zou in het bijzonder kunnen gelden voor eenverdieners met een laag inkomen. Deze groep zal zich mogelijk snel terugtrekken van een actieve bijdrage aan de arbeidsmarkt.

\section{Noten}

1 Brief van staatssecretaris Van Hoof aan de Tweede Kamer van 4 oktober 2005.

2 Dit betreft steeds dezelfde vraag die was opgenomen in het 'Leefsituatieonderzoek' van het CBS: van 1977 t/m 1989 was dit het LSO (LeefSituatie Onderzoek), van 1989 t/m 1996 was dit het DLO (Doorlopend Leefsituatie Onderzoek), en sinds 1997 was dit het POLS (Permanent Onderzoek LeefSituatie).

3 Alle scores zijn zo gehercodeerd dat er een getal tussen de 0 en 100 ontstond, waarbij tevens gold dat hoe hoger de waarde, des te hoger het 'risico'.

\section{Literatuur}

Andries, F., I. Houtman \& C. Hupkens (2004). Kerncijfers Arbeid. In I.L.D. Houtman, P.G.W. Smulders \& D.J. Klein Hesselink (red.). Trends in arbeid 2004. Hoofddorp: TNO Arbeid.

Bensing, J.M. \& K. Schreurs (1995). Sekseverschillen bij moeheid. Huisarts en Wetenschap, 33 (9): 412-421.

Breedveld, K. \& A. van den Broek (2004). De veeleisende samenleving; De sociaal-culturele context van psychische vermoeidheid. Den Haag: Sociaal en Cultureel Planbureau.

Christis, J. (1998). Arbeid, organisatie en stress. Een visie vanuit de sociotechnische arbeids- en organisatiekunde. Academisch proefschrift, Universiteit van Amsterdam.

Houtman, I. (2005), Work-related stress. Topic report for the European Working Conditions Observatory (EWCO), http://www.eurofound. eu.int/ewco/reports/TN0502TR01/TN0502TR01. htm

Houtman, I., F. Otten \& A. Venema (2001). Kerncijfers arbeid, gezondheid en sociale zekerheid. In P.G.W. Smulders, I.L.D. Houtman \& D.J. Klein Hesselink (red.). Trends in arbeid 2002 (pp. 69102). Alphen a/d Rijn: Kluwer.

Karasek, R. \& T. Theorell (1990). Healthy Work. New York: Basic Books.

Kauppinen, K., R. Kumpilainen, I. Houtman \& S. Copsey (2003). Gender issues in safety and health at work: A review. European Agency for Safety and Health at Work. Luxembourg: Office for Official Publications of the European Communities.

Kristensen, T.S., J.B. Bjorner, K.B. Christensen \& V. Borg (2004). The distinction between work pace and working hours in the measurement of quantitative demands at work. Work \&) Stress, 18(4): 305-322.

Lange, A. de (2005). What about causality? Examining longitudinal relations between work characteristics and mental health. Academisch Proefschrift, Radboud Universiteit, Nijmegen.

Otten, F. \& I. Houtman (2002). Werkdruk stabiliseert. Economisch $\oplus$ Statistische Berichten, 22: 159.

Paoli, P. \& Merllié, D. (2001), Third European Survey on Working Conditions 2000, Luxembourg: Office for Official Publications of the European Communities. http://www.eurofound.eu.int/publications/htmlfiles/ef0121.htm

Proper, K.I., P.M. Bongers, J. de Jonge, I.L.D. Houtman \& M.A.J. Kompier (1999). SMASH: Study on Musculoskeletal disorders, Absenteeism, Stress and Health. Deelrapport 4: Psychische klachten en werkkenmerken. Hoofddorp: TNO Arbeid.

Smulders, P.G.W. \& I.L.D. Houtman (2004), Oorzaken van werkdruk: een onderbelicht thema. Tijdschrift voor Arbeidsvraagstukken, 20(1): 90-106. 
Taris, T.W., M.A.J. Kompier, A.H. de Lange, W.B. Schaufeli \& P.J.G. Schreurs (2003). Bevordert het werk het leren van leraren? Een longitudinale toets van de actief leren-hypothese in Karasek's Demand-Control-model. Gedrag e) Organisatie, 16: 142-167.

Vaas, S., S. Dhondt, M.H.H. Peeters \& J. Middendorp (1995). De WEBA-methode. Deel 1. WEBAanalyse handleiding. Alphen a/d Rijn: Samsom Bedrijfsinformatie.

Veerman, T.J., Molenaar, P.G.M., Burg, C.L. van der, \& R. Hoffius (2004). De Meerwaarde van het Arboconvenanten-Aanpak. Een eerste evaluatie op basis van beschikbare bronnen. Den Haag: SZW (werkdocument no. 304).
Veerman, T.J., C.G. Schoemaker, B. Culenaere \& R.V. Bijl (2001). Psychische arbeidsongeschiktheid. Doetinchem: Elsevier.

Wiezer, N., P. Smulders, \& R. Nelemans (2005). De invloed va organisatiekenmerken op werkdruk in organisaties. Tijdschrift voor Arbeidsvraagstukken, 21 (3): 228-244.

Zijlstra, F.R.H., M.J.D. Schalk \& R.A. Roe (1996). Veranderingen in de arbeid: Consequenties voor werkenden. Tijdschrift voor Arbeidsvraagstukken, 12(3): 251-263. 